\title{
Observation on the Quality of Lecturer Performance Based on Computer Self-Efficacy, Organizational Culture and Motivation
}

\author{
Ulfah Mediaty Arief ${ }^{1}$, Haryono $^{2}$, Dwi Yuwono Puji Sugiharto ${ }^{3}$, Achmad Rifai ${ }^{4}$ \\ \{ulfahmediatyarief@mail.unnes.ac.id ${ }^{1}$, fransharyono@mail.unnes.ac.id ${ }^{2}$, \\ dypsugiharto@mail.unnes.ac.id $\left.{ }^{3}\right\}$ \\ Graduate School Program, Universitas Negeri Semarang, Indonesia ${ }^{1,2,3,4}$
}

\begin{abstract}
Lecturer performance in Indonesia based on accordance with publication was not sufficiently high as low as its citation level. This is caused by several factors such as individual competence, amount of effort, computer self-efficacy, organizational culture, and motivation. This article reveals how much the effect of lecturer's computer self-efficacy, organizational culture, and motivation toward the quality of lecturer performance. The amount of effect will be measured both simultaneously and partially. Data collection in this study used a survey method involving 37 lecturers as samples. Data is then analyzed using multiple regression analysis and path analysis. The result of this research showed that computer selfefficacy on lecturers' organizational culture and motivation simultaneously give a positive and significant effect on the quality of lecturer performance. The information technology and organizational culture partially give a positive and significant effect on the quality of lecturer performance. Meanwhile, lecturer motivation has a negative effect on lecturer performance.
\end{abstract}

Keywords: Information Technology, Lecturer Performance, Motivation, Organisational Culture.

\section{Introduction}

Performance is the record of results achieved from specific jobs or certain activities within certain period [1]. The quality and commitment of lecturer are the main key of the success of higher education boards [2], [3]. Lecturers are important component to achieve high-qualified higher education [4]. Lecturers as the ones who conduct teaching will give impact on the quality of process and output of the higher education[5]. Lecturer performance is supposed to be in line with Three Pillars of Higher Education compromising education, research and community service. One of the indicators of lecturer performance can be seen from the sophisticated publication conducted by those lecturers coming from either research or community service. According to Pikiran Rakyat (2018), the publication conducted by Indonesian lecturers were 5.125 literatures which was under Malaysia having achieved 5.999 publication. Although the number of publication of Indonesian lecturers is on the $2^{\text {nd }}$ rank in ASEAN, the citation level is coming down [6]. Furthermore, in 2019, there were 2.250 professors who did not conduct any research and publication [7]. 
According to Joshua Olusegun Peleyeju (2013), the management of higher education should guarantee the assessment of lecturer performance and management quality thoroughly. Bai, Hussain, Rajput, \& Khoja (2014) stated that the evaluation of lecturer performance turns into serious challenge for the stakeholder of higher education. Several main factors influencing the lecturers' performance are individual competence to do several tasks, the effort they contribute and the support from organization [9].

Some researches showed that the competence in using information technology of each individual gives impact to one's performance to achieve the organization's goals [10]-[12]. A research from Abbas et al., (2014) showed that technology highly increased employees' productivity in saving time. Karsen (2015) figured out that the effect of implementing IT in higher education for lecturers' performance is that IT has huge effect in improving lecturer performance in delivering materials to students as well as improving students' quality. One's mastery in IT can be seen through computer self-efficacy. Computer self-efficacy is perceived as an individual's evaluation about his competencies in using technology [14] The one with high self-efficacy has ability in doing any tasks according to the target [15].

Besides the factor of competency in using technology which is called computer selfefficacy, the organizational culture also gives significant and positive impact to the performance [16]. In the field of company, organizational culture also brings positive impact to increase the performance [17]. [18] concluded that organizational culture is a set of values, principles, traditions and ways shared by the members of organization which influence the ways they behave.

Furthermore, Mangkunegara (2012:13) revealed that factors influencing the performance's achievement are ability and motivation. Motivation to work is also one of the factors which influence lecturer performance [19], [20]. Motivation is a psychological condition which boost one's behavior to achieve the expected goals and maintain certain behaviors directed to certain goals [21].

Motivation gives positive and significant effect to the company performance (Ayu \& Suprayetno, 2008). In the term of higher education, motivation to work also gives positive and significant effect to the lecturer performance [22]. Samuel et al., (2015) stated that there is a positive and significant relation between motivation and performance in which motivation contributes $79,5 \%$ among the variations of performance.

The result of research (2012) using staffs in Ghana University as its object showed that motivation is meaningful and directing to initiation and innovation. The research by Olusadum \& Anulika (2018) informed us that motivation to work also influences the performance of staffs in Alvan Ikoku Federal College of Education (AIFCE).

According to the previous factors influencing lecturer performance, this article will reveal the direction of effect of computer self-efficacy, organizational culture and self-motivation owned by lecturers in higher education toward their performances.

\section{Methods}

The research method applied was quantitative approach. The process of collecting data was done by using survey method. The procedure of taking sample was undertaken randomly. The instrument used to collect data was questionnaire. The population of this research was 37 lecturers in Faculty of Engineering Universitas Negeri Semarang.Lecturer performance was used as dependent variable while the independent variable was organizational culture, 
motivation and computer self-efficacy. The track analysis was applied to find out the relation of causality relation between variables of information technology, organizational culture, motivation and performance and to examine the existence of direct and indirect relation in this research. Tests conducted for this research are data validity, reliability, normality, double-regression, $\mathrm{t}$ test and $\mathrm{f}$ test.

\section{Results and Discussions}

Based on data from questionnaire with 44 instrument questions of four variables i.e computer self-efficacy, organizational culture, motivation and lecturer performance, those 44 instruments were divided and tested based on its variables, with $\mathrm{X} 1$ as variable of information technology, $\mathrm{X} 2$ as organizational culture, $\mathrm{X} 3$ as motivation and $\mathrm{Y}$ as lecturer performance.

Validity test was conducted by comparing the score of Pearson Correlation in total column with score of $r$ table on $n$ (number of sample) $=37$ with significance $5 \%$. The score of $r$ table used degree of freedom (df). The formula of $\mathrm{df}=\mathrm{n}-2$, where $\mathrm{n}$ is number of sample, so $\mathrm{df}=37-2=35$. The score of $\mathrm{r}$ table for $\mathrm{df}=35$ and significancy rate $5 \%$ is 0.325 . The test criteria is if $r$ score from observation result is bigger than score of $r$ table or $r_{0}>r_{t}$, so the questions are valid. The significance test can also be conducted by comparing score Sig. (2 tailed) with significance rate $5 \%(0.05)$. If score of Sig. (2 tailed) is smaller than 0.05 , the questions are valid.

The correlation calculation result using the formula of Pearson showed that there were 8 valid questions on variable of information technology among 15 questions. For the variable of organizational culture, the validity instrument was by $100 \%$ from 11 instruments while for variable of motivation, the validity instrument was $100 \%$ from 8 instruments. Then, for variable of lecturer performance, those 10 instruments were valid at all.

The ways to test instrument's reliability in this research was by applying formula of Cronbach Alpha $>0.70$ with following explanation:

a. If the result of Alpha coefficient $>$ significance rate $70 \%$ or 0.70 , the questionnaire is reliable.

b. If the result of Alpha coefficient $<$ significance rate $70 \%$ or 0.70 , the questionnaire is unreliable.

The result of reliability test of all variables can be seen from the following table 1:

Table 1. The result of reliability test

\begin{tabular}{lccc}
\hline Variables & $\begin{array}{c}\text { Cronbach's } \\
\text { Alpha }\end{array}$ & $\begin{array}{c}\text { Criteria of } \\
\text { Cronbach's } \\
\text { Alpha }\end{array}$ & Note \\
\hline $\begin{array}{l}\text { Computer } \\
\text { self efficacy }\end{array}$ & 0,719 & 0,700 & Reliable \\
$\begin{array}{l}\text { Organization } \\
\text { al culture }\end{array}$ & 0,808 & 0,700 & Reliable \\
$\begin{array}{l}\text { Motivation } \\
\text { Lecturers' } \\
\text { performance }\end{array}$ & 0,892 & 0,700 & Reliable \\
& 0,765 & 0,700 & Reliable \\
\hline
\end{tabular}

Source: The result of research data analysis, 2019 
Based on the table 1 above, it can be seen that all variable instruments have score of Cronbach's Alpha $>0,70$ so the instruments of all variables are reliable. The result of normality test with method of graphics P-plot by using program IBM SPSS 23 for windows. Based on figure 1, the data distribution which is drawn through dots which form a pattern following the direction of diagonal line. Therefore, the assumption of data normality can be fulfilled. It means that data is normally distributed. Besides normal graphics of P-plot, statistical analysis was also carried out by using the test of Kolmogorov-Smirnov (K-S) as the following explanation:

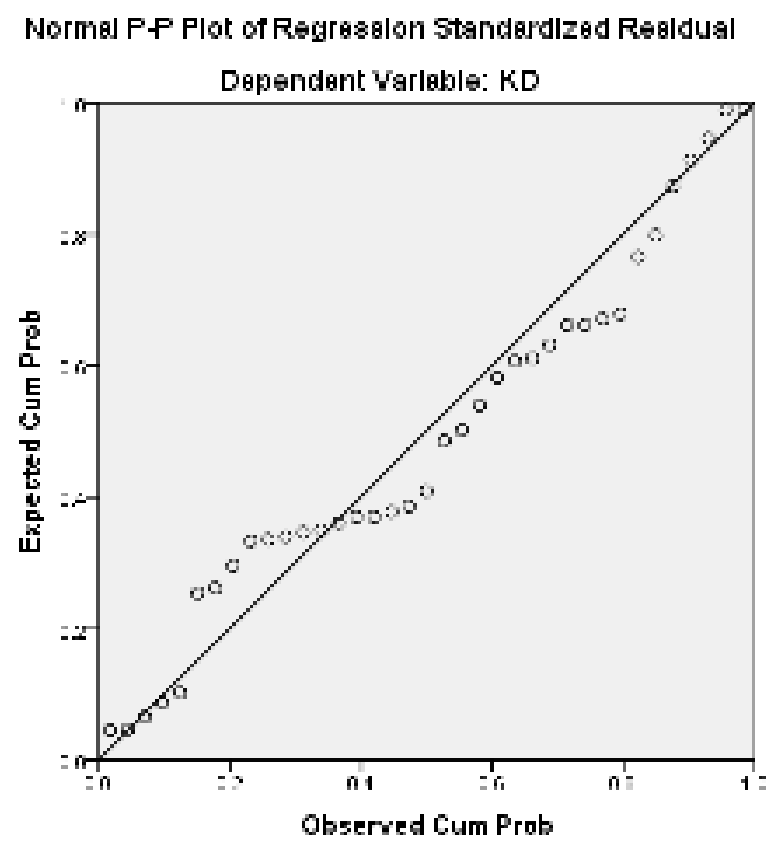

Figure 1. Normal graphics of P-P Plot

Based on normality test using the test of Kolmogorov-Smirnov (K-S), the score of KSZ is by 0.758 and Asymp.sig. is by 0.614 . Since those scores are bigger than the determined alpha ( $\alpha$ ) which is 0.050 , it can be absolutely concluded that data proposed for this research fulfill the assumption of normality which means there is residual data that is normally distributed.

Table 2. Coefficient of Regression

\begin{tabular}{lccc}
\hline Variables & Beta & t & Sig. \\
\hline (Constant) & 2.569 & .446 & .659 \\
CSE & .598 & 2.737 & .010 \\
BO & .483 & 2.181 & .036 \\
M & -.204 & -.852 & .400 \\
& & & \\
\hline
\end{tabular}


Based on the data on table 2 above, the calculation of the equation of double linier regression can be seen with positive-scored constanta by 2.569 which means that if information technology, organizational culture and motivation are constant, the increase of lecturer performance is 2.569 unit. Regression coefficient of variable computer self-efficacy (CSE) on lecturers' performance is by 0.598 . This showed that leadership gives positive and significant effect to lecturers' performance.

Regression coefficient of variable organizational culture (BO) on performance is by 0.483. This showed that motivation influences positively and significantly to lecturers' performance. Regression coefficient of variable motivation (M) to performance is by -0.204 . This showed that motivation has negative impact to lecturers' performance.

From the analysis on the table 2 above, we can make equation (1) and (2), and track analysis on figure 2 .

$$
\mathrm{Y}=\mathrm{a}+\mathrm{b}_{1} \mathrm{X}_{1}+\mathrm{b}_{2} \mathrm{X}_{2}+\mathrm{b}_{3} \mathrm{X}_{3}+\mathrm{e}
$$

$$
\mathrm{KD}=2,569+0.598 \mathrm{TI}+0,483 \mathrm{BO}-0,204 \mathrm{M}+\mathrm{e} .
$$

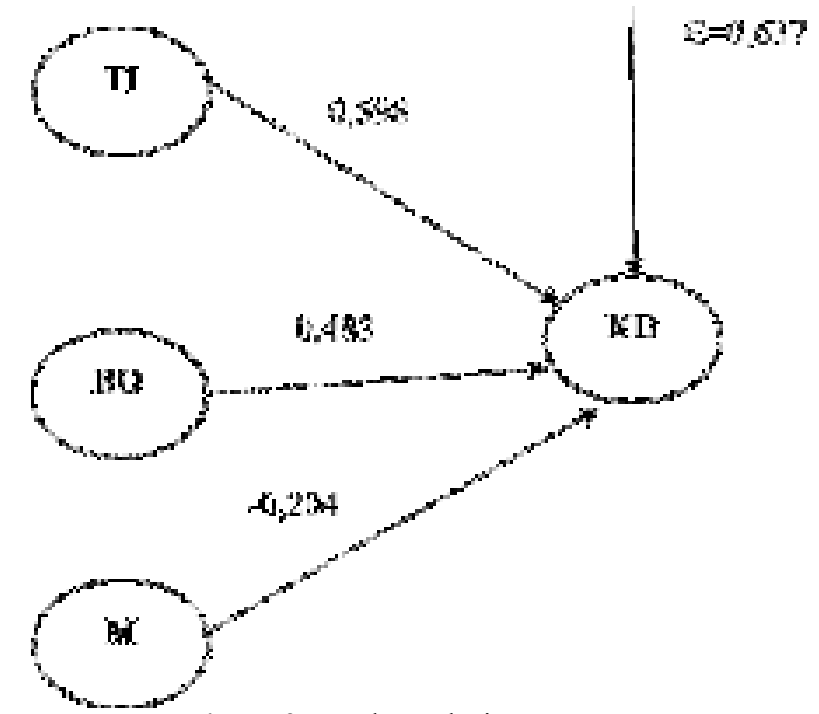

Figure 2. Track Analysis

Table 3. Partial test

\begin{tabular}{ccc}
\hline Variable & t & Sig. \\
\hline (Constant) & .446 & .659 \\
CSE & 2.737 & .010 \\
BO & 2.181 & .036 \\
M & -.852 & .400 \\
\hline
\end{tabular}


Based on t-test above, it can be interpreted that variable computer self-efficacy has tcount by 2.737 with significance by 0.10 while the score of $t$-table as the standard is by 2.035 . Since there are 37 samples.t-count for computer self-efficacy $>t$ table and significance score is by $0.010<0.05$, it can be inferred that variable of computer self-efficacy gives positive and significant impact to lecturer performance.

For variable organizational culture, t-count is by $2.181>\mathrm{t}$ table and significance score is $0.036<0.05$, so it can be inferred that variable of organizational culture gives positive and significant effect to lecturer performance. For variable motivation, t-count is by -0.852 with significance score is 0.400 , while $\mathrm{t}$-table is by 2.035 . Since there are 37 samples, $\mathrm{t}$-count $<\mathrm{t}$ table or significance score $>0.05$, so it can be inferred that variable of motivation gives negative effect to lecturer performance.

Table 4. Simultaneous Test

\begin{tabular}{lcc}
\hline Model & F & Sig. \\
\hline Regression & 7.834 & $.000^{\mathrm{b}}$ \\
Residual & & \\
Total & & \\
\hline
\end{tabular}

The result of score $f$ test is by 7.834 , while based on $f$ table by considering 4 research variables and 37 samples, $\mathrm{f}$ table is 2.89 . Therefore, $\mathrm{f}$ test is bigger than $\mathrm{t}$ table so the variable of computer self-efficacy, motivation to work and self motivation hand in hand give positive and significant impact to lecturer performance.

\section{Conclusion}

Based on the result and analysis of research data with sample of 37 lecturers in Faculty of Engineering, Universitas Negeri Semarang, it can be inferred that variable of computer self-efficacy, organizational culture and motivation hand in hand impact positively and significantly to lecturer performance by 7.384. Further, variable of computer self-efficacy and organizational culture give positive and significant effect to lecturer performance. However, variable motivation impact negatively to lecturers' performance. Variable of computer self-efficacy has positive and the most significant effect to lecturer performance. 


\section{References}

[1] A. P. Mangkunegara, Manajemen sumber daya manusia perusahaan. Bandung: PT Remaja Rosdakarya, 2009.

[2] B. Amang, "ANALISIS KINERJA DOSEN PADA PROGRAM STUDI," Media Ris. Bisnis Manaj., vol. 11, no. 2, pp. 140-173, 2011.

[3] J. D. Angrist, "Consequences of Employment Protection? The Case of The Americans with Disabilities Act," no. October 2001, 2014.

[4] Ramli and N. Jalinus, "Evaluasi Kinerja Guru Sekolah Menengah Kejuruan Sumatera Barat Pascasertifikasi," J. Penelit. dan Eval. Pendidik., vol. 17, no. 1, pp. 72-87, 2013.

[5] D. A. Kusumajati, "The Influence of Lecturers' Competencies towards Students' Performance Motivation : A Case Study at Higher Education," pp. 173-176, 2017.

[6] D. Seftiawan, "Akhirnya Lampaui Singapura, Publikasi Ilmiah Indonesia ke-2 ASEAN," Pikiran Rakyat, 11-Apr-2018. [Online]. Available: https://www.pikiranrakyat.com/pendidikan/2018/04/.

[7] A. Prawitasari, "Ini Kritik Menristekdikti, 5.500 Profesor, Hanya 2.250 Orang yang Aktif Meriset," solopos, 2019. .

[8] S. Bai, S. Hussain, Q. Rajput, and S. A. Khoja, "Faculty Performance Evaluation System : An ontological approach,” Proc. IEEE/ACS Int. Conf. Comput. Syst. Appl. AICCSA, pp. 117-124, 2014.

[9] R. L. Mathis and J. H. Jacson, Human Resource Management, 12th ed. United States of America: Thomson South-Western, 2000.

[10] R. Jahanian, Z. N. Nav, and A. Asadi, "The Impact of Information Technology and Communication Training on the Performance of Human Resources in Educational Organizations,” World Appl. Sci. J., vol. 16, no. 6, pp. 850-855, 2012.

[11] Z. Khaled, K, "The Effect of Information and Communications Technologies ( ICT ) in the Jordanian Universities," Inf. Knowl. Manag., vol. 4, no. 12, pp. 122-133, 2014.

[12] K. Bhakta, "Impact of Information Technology on Teaching-Learning Process," Int. Res. J. Interdiscip. Multidiscip. Stud., vol. 7969, no. 131, pp. 131-138, 2016.

[13] J. Abbas, A. Muzaffar, H. K. Mahmood, M. A. Ramzan, S. Sibt, and U. Hassan, "Impact of Technology on Performance of Employees ( A Case Study on Allied Bank Ltd, Pakistan ) Director NUML , Institute of Business and Finance, Ali Block Garden Town Lahore , Pakistan," World Appl. Sci. J., vol. 29, no. 2, pp. 271-276, 2014.

[14] R. Handayani, "ANALISIS PENGARUH COMPUTER ANXIETY DAN SELF EFFICACY TERHADAP KEAHLIAN PENGGUNAAN INTERNET PADA MAHASISWA Rini Handayani Dosen DPK STIE Atma Bhakti Surakarta,” Ris. Manaj. dan Akutansi, vol. 1, no. November 2010, pp. 64-77, 2010.

[15] M. Yakin and O. Erdil, "Relationships Between Self-Efficacy and Work Engagement and the Effects on Job Satisfaction: A Survey on Certified Public Accountants," in Procedia - Social and Behavioral Sciences, 2012, pp. 370-378.

[16] A. Ritawati, "Pengaruh Kepemimpinan Transformasional Dan Budaya Organisasi Terhadap Kepuasan Kerja Dan Kinerja Karyawan PT . Jamsostek ( Persero ) Cabang Surabaya,” J. Ilmu Ekon. Manaj., vol. 9, no. 1, pp. 82-93, 2013.

[17] I. Ayu and A. Suprayetno, "Pengaruh Motivasi Kerja , Kepemimpinan dan Budaya Organisasi Terhadap Kepuasan Kerja Karyawan serta Dampaknya pada Kinerja Perusahaan ( Studi kasus pada PT . Pei Hai International Wiratama Indonesia ),” J. Manaj. DAN KEWIRAUSAHAAN, vol. 10, no. 2, pp. 124-135, 2008.

[18] S. P. Robbins and M. Coulter, Management, 11th ed. United States of America: Pearson Education Limited, 2012.

[19] L. Samuel, A. Kwapong, and E. Opoku, "The Effect of Motivation on the Performance of Teaching Staff in Ghanaian Polytechnics: The Moderating Role of Education and Research Experience,” Int. J. Educ. Res., vol. 3, no. 11, pp. 35-48, 2015.

[20] A. Afful-broni, "Relationship between Motivation and Job Performance at the University of 
Mines and Technology, Tarkwa , Ghana: Leadership Lessons," vol. 3, no. 3, pp. 309-314, 2012.

[21] A. Wigfield, J. T. Guthrie, S. Tonks, K. C. Perencevich, J. T. Guthrie, and K. C. Perencevich, "Children 's Motivation for Reading: Domain Specificity and," no. October 2014, pp. 37-41, 2014.

[22] H. Riyadi, B. S. Utomo, and A. Masatip, "Pengaruh Komunikasi , Motivasi Kerja Dan Kompetensi Terhadap Kepuasan Kerja Serta Implikasinya Pada Kinerja Dosen Pada Perguruan Tinggi Pariwisata Swasta Di Jawa Barat," vol. 7, no. 2, pp. 73-90, 2017. 